\title{
4. Towards Leader Democracy?
}

\section{Jan Pakulski and John Higley}

\section{Introduction}

Three trends are apparent in today's liberal democracies: an ever more pronounced focus on political leaders; a heightening of this focus by electronic media; and more aggressive actions by leaders and the elites in which they are embedded. These trends reinforce each other and move the concrete physiognomy of liberal democracies to 'leader democracies'. This move prompts, in turn, a conceptual integration of leaders and elites, together with amendments to Max Weber's model of leader democracy (Weber 1978; Körösényi 2005).

Leaders and elites are clearly interdependent: leaders provide elites with political focus and direction; elites envelope leaders and give them the political muscle essential for effective action. Yet leaders and elites inhabit quite separate theoretical and research domains. Each is the subject of a distinct and large literature and major school of thought. Historians routinely focus on leaders in the guise of 'great men'. Outside the historians' province, analyses of leaders and leadership are anchored in social psychology and, as perusals of airport bookracks show, in the study of business organisation and management. In political sociology treatments of leaders typically centre on leader cults, populism, and authoritarianism, as well as Weber's thesis about charismatic authority. But Weber's concept of 'leader democracy' is seldom employed (Körösényi 2007). Elites, by contrast, are widely regarded as a critical variable in the founding and working of democracy (for example, Sartori 1987; Huntington 1991; Higley and Burton 2006). In this elite-oriented context, leaders are treated as the most prominent elite persons who provide policy direction to elites. Elite studies concentrate on groups and circles of power wielders and usually fold leaders into these configurations (for example, Higley et al. 1991). ${ }^{1}$

\section{Leader democracy: Weber and beyond}

Weber developed his concept of leader democracy (Führerdemokratie, also translated as 'leadership democracy') in the context of early twentieth-century trends toward professional politicians, bureaucratic states and mass democracies, trends that Weber observed mainly in Great Britain and the United States and that he anticipated in post-World War I Germany. He depicted leader democracy as a distinctive political order marked by the domination of charismatic leaders over professional parliamentary politicians, party machines, and state bureaucracies (1978: 241-71, 1111-55 and 1459-60). Domination by these leaders rests on the popular acclamation and public trust that they evoke through the 
use of demagogy during competitive electoral contests. Leader democracy is, thus, a representative political system in which charismatic leaders rule but citizens participate in their selection. The diffuse and highly personalised character of the mass support that such leaders obtain insulates them from public pressures once in office and this frees them to act responsibly in the public interest. They are able to rise above the sectional pressures and the crude horse-trading of narrow career interests in which professional politicians are immersed.

It is important to stress that for Weber leader democracy entails, above all, competitive elections that produce mandates to govern. Winning elections is the principal imperative, the main source of political power and the key test of political leadership. Parties, parliaments and leaders must cope with this electoral imperative and accept that their success depends vitally on winning votes. Parties do this by developing financial resources, professional staffs and strategies for persuading voters of their leader's personal superiority. Constituting forums in which leaders can display superior oratorical talents and personality traits, parliaments enable charismatic leaders to emerge and gain 'the confidence of the masses'. State bureaucracies - in Weber's eyes the 'completely indispensable' element of modern rule - submit to charismatic leaders backed by mass electoral support. In order for democracy to work effectively, in short, charismatic leaders who win the confidence of mass electorates are essential.

Weber held that charismatic leaders are individuals with 'great political instincts' who emerge only through political struggles, not through bureaucratic careers (1978: 1414). However, bureaucratic party and state hierarchies may prevent or at least hinder the emergence and the freedom of such leaders once they gain power because 'the whole nature of modern officialdom is most unfavourable to the development of political autonomy'. Effective leaders, in other words, are not only rare but also vulnerable to bureaucratic constraint. But ideally, charismatic leaders and high-ranking bureaucrats complement each other because they are located in different segments of political elites, and this is what a parliamentary democracy requires for success. ${ }^{2}$

Weber was adamant that charismatic leaders provide both parliamentary and mass leadership in the context of small political elites.

The broad mass of deputies functions only as the following for the leader or few leaders who form the government, and it blindly follows them as long as they are successful. This is the way it should be. Political action is always determined by the 'principle of small numbers', that means, the superior political manoeuvrability of small leading groups. In mass states, this Caesarist element is 'ineradicable'. (1978:1414). 
In Weber's view, however, charismatic leaders do not emerge ineluctably from masses, classes or even particular segments of elites. Charisma is rare, and those who possess it 'capture' audiences and impose themselves on followers. 'For it is not the politically passive "mass" that produces the leader from its midst, but the political leader recruits his following and wins the mass through "demagogy". This is true even under the most democratic form of the state.' (1978:1457). If the leader's charisma and determination are accompanied by accountability to parliament, this imposition enriches politics and assures its autonomy vis-à-vis party and state bureaucrats. But where this does not occur, there is either a 'passive' democracy controlled by professional politicians and bureaucrats or a volatile 'plebiscitary' democracy (1978:1460).

\section{The dominance of leaders today}

Weber's depiction of leader democracy accords with current trends in liberal democracies, whether parliamentary or presidential in form. One of their key features is the dominance of assertive leaders such as George W. Bush, Tony Blair, John Howard, Nicholas Sarkozy, Angela Merkel, Silvio Berlusconi and, more briefly, the Kaczynski twins in Poland. Voters focus almost exclusively on such leaders' likeability and other personality traits that inspire trust. Leaders' intellectual capacities, ideological and issue orientations, and policy-making experience and skill are of secondary importance at best. Leaders who inspire trust, project strength and gain wide appeal define issue agendas, overshadow party platforms and dominate elections. Elections are today mainly referendums on competing leaders' images. ${ }^{3}$

This dominance of leaders extends well beyond electoral contests. At international and national 'summit' meetings leaders fill the stage, their upbeat or downcast demeanours being most of what is reported about such gatherings. 'World leaders' are expected to tackle gigantic problems: economic globalisation, climate change, water shortages, energy supplies, WMD proliferation, terrorist threats, disease pandemics, criminal syndicates, and much more. One could be forgiven for thinking that world and national fates lie in the hands of a few leaders who are the foci of media and public attention.

This is a significant change from politics in liberal democracies during the decades before and after World War II. Then the role of leaders was to voice coherent ideologies, party programs and election platforms reflecting issues of broad public concern. Today, however, selecting a leader who is likeable, who has no skeletons in the closet, and for whom an attractive media image can be fashioned is seen as the key to success in democratic politics. Parties have become vehicles for leaders and governments are more and more synonymous with the prime ministers and presidents who head them. This change is particularly striking in parliamentary democracies that long emphasised party government and collective cabinet decision-making and responsibility. Most recent European electoral 
competitions - in Blair's Britain, Fogh Rasmussen's Denmark, Merkel's Germany, Berlusconi's Italy, Zapatero's Spain — have emulated the strongly leader-centred contests of the United States and the semi-presidential systems of France and Poland.

One cannot interpret this increased focus on leaders as simply the 'Americanisation' of parliamentary democracies or the necessary response to terrorism and threats to national security. American influence on parliamentary democracies has always been strong, but today's preponderant focus on leaders is of relatively recent vintage and it antedates the terrorist spectre, though there is no doubt that terrorism reinforces the concentration on leaders. Broader and deeper changes in democracies, both parliamentary and presidential, lie behind the change.

At the most general level, strong centripetal pressures are forcing the concentration of power at the apexes of political, business, and other key elites. Power is concentrated in prime ministers and opposition leaders who are clearly above rather than primus inter pares in cabinets and shadow cabinets. As shown by Donald Savoie (2008), Canada and Britain now approximate 'court governments' more than cabinet governments. Effective power in both countries rests with prime ministers and a small group of trusted courtiers. ${ }^{4}$ Similarly, political observers in Australia (for example, McAllister 2003) note that cabinet ministers and their shadow counterparts operate increasingly as political conduits for leaders, while public service department secretaries are often political scapegoats who take the blame for policy failures.

This focus on leaders goes hand in hand, of course, with the waning of cleavage-based mass parties (Volksparteien). Jean Blondel (2005) observes that the structural bases of such parties have weakened greatly, and their ideological-programmatic competitions, which once addressed stable and loyal mass constituencies, especially class-based ones, have largely ended. Ideological blueprints for socialism, liberalism and conservatism have been abandoned as idioms for mobilising support, and they no longer serve as frameworks for policy-making. Instead, political leaders stitch together more or less ad hoc policy packages, parts of which are often copied from packages that leaders in other countries have marketed successfully. These assemblages are much more idiosyncratic than the programs of the earlier Volksparteien. Although they all assume a market economy, an electoral democracy and a national identity, the packages contain mixes of ideologically incongruous elements. Thus, a laissez-fare commitment to economic deregulation is packaged with collectivist commitments to environmental protections, new government health care programs or measures to alleviate the plights of home-owners. The packages are pieced together and presented by leaders and their coteries of close advisers and they are altered according to what incoming polling and focus group data suggest is most saleable. 
Such manoeuvres attract the lion's share of media attention and leaders make their presentations media events. Leaders are portrayed as the key agents of change, especially when risky and painful policies have to be introduced and voters must be persuaded to accept them as bitter pills to be swallowed. ${ }^{5}$

Parties thus become 'leader parties' whose role is restricted to anointing leaders and financing campaigns in the hope of participating in the distribution of political spoils if their leader wins. In some cases (for example, Blair and Brown in the UK, Howard and Rudd in Australia), parties subordinate themselves to popular leaders and give them a free hand in reforming party programs and election strategies. In other cases (for example, Berlusconi in Italy, the Kaczynski brothers in Poland), leaders create their own political parties and use them as personal vehicles for gaining power. In general, leaders now bring parties to power rather than the other way round. ${ }^{6}$

The increasing focus on leaders is also a response to the growing complexity of political issues and sense of uncertainty and risk about unintended policy consequences. Ideologically robust parties and their programs were suited to times of greater certainty when policy choices were clear and policy outcomes were relatively predictable. But such certainties, which accompanied the organised superpower politics of the Cold War period and voters' innocence about environmental, globalisation and many other matters, have attenuated. As anticipated and detailed by Danilo Zolo (1992), in today's atmosphere of democratic complexity, voters fall back on leaders as guides and innovators who are ostensibly more capable of responding flexibly and rapidly to risks and uncertainties than the rigid party machines of yore. Leaders who grapple with 'issues whose complexities lie beyond the grasp of mass publics' (Zakaria 2003:241) offer vague visions that they articulate in charismatic ways. At this writing, the artfully presented vision of Senator Barrack Obama, the Democratic presidential candidate in the US, that 'change' from old to new politics is a matter of inspired leadership and collective will ('Yes we can!') is a case in point.

A public arena suffused by mass media facilitates much of this. The mass media, especially electronic media that create feelings of intimacy, are the natural allies of charismatic leaders. They accentuate the images of these leaders as mass persuaders, tone-setters, figures with whom voters can identify, and providers of reassurance. This media role is obviously great, especially during election campaigns that are now quite prolonged, even 'permanent campaigns'. The media cater to consumers' short attention spans and quickly grasped images, and this encourages hyperbole and spectacle. To suit the need for drama, brevity and simplicity, campaigns are framed as 'horse races' mostly devoid of policy detail and nuance (Denemark et al. 2007). Leaders' personalities, especially their quirks, are the core idiom and highlighting personal differences between leaders the modus operandi. 
Leader-media relations are of course symbiotic. Leaders and aspiring leaders carefully cultivate relations with the media and work hard to buff their media images. Conscious of the impact that personalised media exposure has on voters, they comport themselves as celebrities. Indeed, growing numbers of leaders have previously been media celebrities with the advantages of 'recognition' and expertise in using the media. Leaders surround themselves with media-savvy advisers, PR experts and spin-doctors. Their image-shaping machines include public opinion pollsters and strategists who elbow aside advisers on substantive issues and ignore prosaic concerns of local party and faction bosses (Paisley and Ward 2001). Use of this image-shaping expertise strengthens leaders' positions vis-à-vis parliamentary and party colleagues, who, as background figures, see their political careers hinging on how leaders fare in voter approval ratings.

Voter-media relations are also symbiotic. Brief, dramatic and, above all, personality-focused media presentations suit voters well. This is because voters like to think of themselves as skilled in judging character, while few see themselves as capable of assessing complex and often-recondite policy issues and dilemmas. Forming an opinion about a leader as friendly, sympathetic, trustworthy, determined, committed, or as aloof, cold and uncaring is easily accomplished with the assistance of a few minutes of media exposure. Once formed, such voter judgments are relatively unshakeable, short of some scandalous revelation about a leader's personal behaviour.

\section{Leonine leaders and elites}

The strong focus on leaders and the influence of mass media coincide with a shift in the demeanours of political leaders. Starting in the 1980s more forceful, aggressive and peremptory leaders have become ascendant, displacing earlier generations of leaders who relied on quiet negotiation and compromise. The new type of leader indulges in demagogy more freely and makes clear a readiness to use coercion (Pakulski 2005; Higley and Pakulski 2007). In Weberian parlance, they are 'Caesarist' leaders; in the language of Machiavelli and Pareto, they exemplify the triumph of 'lions' over 'foxes'.

The two leaders who pioneered this more leonine style were Margaret Thatcher and Ronald Reagan (see for example, Little 1988). Each emerged out of a relatively uncompromising elite camp, Thatcher from the 'dry' Tory camp, Reagan from the 'anti-detente' camp of Republicans. While cultivating quite different images - Reagan as a humorous and warm man and Thatcher as the outspoken 'Iron Lady' — both reached the political pinnacle as determined 'anti-establishment' leaders and they became close confidants and friends. While differing from Thatcher and Reagan in party colorations, leaders who have subsequently emulated them display more or less the same demeanours: resolute, stubborn, uncompromising, determined, single-minded, nationalistic and fiercely loyal to close allies and staffs. These leaders tend to depict politics as approximating a 
zero-sum struggle between themselves and their enemies, and they justify themselves and actions by proclaiming their fidelity to 'values' that they say are held deeply by 'ordinary' citizens. The new brand of leonine leaders prefers confrontation rather than compromise and the use of force more than diplomatic stratagems. They often claim strong personal religious beliefs and anchor their political stands in morality and the condemnation of political vacillation.

If Pareto's theory of how political elites circulate, cyclically and endlessly, between foxes and lions is brought to bear, the recent ascendancy of leonine leaders reflects the failures of fox-like leaders who were prone to weakness, prevarication, compromise, surrender to sectional interests, opportunism and lack of fortitude. But if the theory of elite circulation is correct, today's more leonine leaders will alienate important allies, incur unacceptable costs in blood and treasure, and become embroiled in destructive conflicts. In path-dependency fashion, these leonine failures will pave the way for a return of more cunning and fox-like leaders who will outwit the lions in future political contests. It is plausible that the fates of George W. Bush, John Howard, Tony Blair and the tough-minded elites that followed them into executive power are a portent, though it is by no means certain that, amid the ominous circumstances facing the US, Australia, Great Britain and other Western countries today, successors will be any less determined and resolute.

\section{Towards leader democracy?}

What does the move to leader democracies imply conceptually? A first implication is that political theory and research must concentrate on leaders, the elites that surround them, and the outlooks and styles that distinguish them over time. This promises a better grip on contemporary political change, and it will revive an analytical and theoretical tradition that has been largely in eclipse since the beginning of the twentieth century. Neo-elite theorists who focus on leaders as key actors, and who analyze preponderant leader and elite outlooks and orientations, chart the direction in which political theory and research should go (Field and Higley 1980).

A second implication is that leadership studies must be unshackled from their excessive focus on pathological 'leader cults' and studies of authoritarianism. This unshackling will open the way to a reconciliation between democratic and elite theories - a reconciliation that is likely to strengthen both by injecting greater realism into democratic theory and discredit perceptions of elite theory as anti-democratic.

Third, the model of 'leader democracy' must be made more robust. One way to do this will be to add a conception of the 'political class' as a sub-elite stratum heavily involved in shaping leaders' images and mass-mediated political opinion. The electronic media's importance in leadership contests requires re-thinking 
the concept of 'political class' as consisting of public intellectuals and political activists - the traditional 'opinion-makers' The political class today has at its core 'image-makers' and 'spin-doctors' who are much more dependent on the patronage and success of leaders than traditional intellectuals and activists. Its members live off leaders, especially leaders of the leonine species.

Finally, the move toward leader democracy requires altering broad conceptions of political elites. The roles played by charismatic leaders as key shapers of elite integration must be brought to centre stage. The integration and normative consensus that distinguishes democratic elites are now affected strongly by the idiosyncratic behaviour of charismatic leaders. Even where elites are well integrated and share a tacit consensus, charismatic leaders are increasingly the key underwriters of this elite configuration and the main guardians and articulators of political game rules. Deep elite divisions that augur political warfare and democratic instability now typically start, first and foremost, among contending leaders and the power struggles in which they engage.

\section{References}

Blondel, Jean, 2005, 'The links between Western European Parties and their supporters. The role of personalization' Occasional Paper 16/2005, Centre for the Study of Political Change (CIRCaP), University of Siena.

Denemark, David, Ian Ward and Clive Bean, 2007, 'Election Campaigns and Television News Coverage: The Case of the 2001 Australian Election', Australian Journal of Political Science, 42:1, pp. 89-109.

Field, G. Lowell and John Higley, 1980, Elitism, London: Routledge \& Kegan Paul.

Higley, John, Ursula Hoffmann-Lange, Charles Kadushin and Gwen Moore, 1991, 'Elite Integration in Stable Democracies: A Reconsideration'. European Sociological Review 7:1, pp. 35-53.

Higley, John and Michael Burton, 2006, Elite Foundations of Liberal Democracy. Lanham: Rowman and Littlefield.

Higley, John and Jan Pakulski, 2007, 'Elite and Leadership Change in Liberal Democracies', Comparative Sociology, 6:1-2, pp. 6-26.

Huntington, S. J., 1991, The Third Wave, Norman, Oklahoma: University of Oklahoma Press.

Körösényi, András, 2005, 'Political Representation in Leader Democracy,' Government and Opposition, 40:3, pp. 358-78.

Körösényi, András, 2007, 'Political leadership: Between Guardianship and Classical Democracy', Paper presented at ECPR Workshop on 'Political 
Leadership: A Missing Element in Democratic Theory', Helsinki, Finland, 7-12 May.

Little, Graham, 1988, Strong Leadership: Thatcher, Reagan and an Eminent Person, Oxford University Press, Melbourne.

McAllister, Ian, 2003, 'Prime Ministers, Opposition Leaders and Government Popularity in Australia', Australian Journal of Political Science, 38:2, pp. 259-77.

Pakulski, Jan, 2005, 'Ascendant Lions? Changes in the Australian Political Elite'. Paper presented at the international conference on 'Changing Patterns of Elite Rule in Advanced Democracies', Ballestrand, Norway, 9-12 June.

Peisley, Michael and Ian Ward, 2001, 'Parties, Governments and Pollsters', Australian Journal of Political Science, 36:3, pp. 553-65.

Sartori, Giovanni, 1987, The Theory of Democracy Revisited, Part I: The Contemporary Debate, Chatham, NJ: Chatham House Publishers.

Savoie, Donald J., 2008, Court Government and the Collapse of Accountability in Canada and the United Kingdom, Toronto: IPAC Series in Public Management and Governance.

Weber, Max, 1978, Economy and Society, Berkeley: University of California Press. Welsh, William, 1979, Leaders and Elites, New York: Holt, Rinehart, Winston.

Zakaria, Fareed, 2003, The Future of Freedom, New York: W. W. Norton.

Zolo, Danilo, 1992, Democracy and Complexity, University Park, PA: Pennsylvania University Press.

\section{ENDNOTES}

${ }^{1}$ Leaders and elites are sometimes yoked together under the all-purpose rubric of 'political leadership' (for example, Welsh 1979), but as analytic categories they remain mutually exclusive. The recent Handbook of Political Sociology contains one reference to leaders and none to leadership; the latest Handbook of Leadership makes no reference to elites at all. Scholars who study leaders and elites toil for the most part in separate vineyards.

2 'Neither the parties' Caesarist character and mass demagogy nor their bureaucratisation and stereotyped public image are in themselves a rigid barrier to the rise of leaders. Especially the well-organised parties that really want to exercise state power [and enjoy the spoils] must subordinate themselves to those who hold the confidence of the masses, if they are men with leadership abilities ... Particularly under the contemporary conditions of [mass democratic] selection, a strong parliament and responsible parliamentary parties, fulfilling their function as a recruiting and proving ground of mass leaders as statesmen, are basic conditions for maintaining continuous and consistent policies.' (1978: 1459).

3 In the Australian context, see McAllister (2003) and Gallop (2005). As McAllister (2003: 259) notes: 'There is little doubt that political leaders have become more politically important over the past half century, in parliamentary as well as in presidential systems. Leaders' images are now as widespread as party symbols during election campaigns, and governments are routinely labelled after their leader, not the party ... Much of this change is attributed to the growth of the electronic media, which find it easier to disseminate visual and oral information through a familiar personality ... Parties, too, consider it advantageous to market political choices to voters through a personality. And for their part, voters prefer to hold an individual accountable for government performance, rather than an abstract institution 
or a political ideal.' The centrality of leaders was apparent in the 2007 federal elections depicted in the media as a leadership contest between John Howard and Kevin Rudd.

4 An analogous trend is observed in the corporate sector where power is concentrated in the hands of chief executive officers with bloated salaries and celebrity statuses akin to those of rock stars.

${ }^{5}$ According to Gallop (2007: 28) 'All governments (and Oppositions) need a centre from which generates the drive to gain, hold and use power. Leaders are that centre in a world of shifting loyalties and increased volatility.'

${ }^{6}$ In addition to those mentioned, leaders who significantly transformed their parties include Margaret Thatcher, Francois Mitterrand, Adoflo Soares, Helmut Kohl, and more recently Paul Keating, Felipe Gonzales, Jose Maria Aznar, Junichiro Koizumi, Helen Clarke, and Nicholas Sarkozy. In addition to Silvio Berlusconi, leaders who formed or transformed parties as personal power vehicles include Jörg Heider and almost all leaders in post-communist Eastern Europe. 